\title{
Urgensi Kebijakan Jaminan Kesehatan Semesta (Universal Health Coverage) bagi Penyelenggaraan Pelayanan Kesehatan Masyarakat di Masa Pandemi Covid-19
}

\author{
F.C. Susila Adiyanta \\ Fakultas Hukum Universitas Diponegoro \\ J1. Prof. Soedarto, SH Tembalang Semarang \\ susilafhundip@gmail.com,fcsusilaadiyanta@lecturer.undip.ac.id
}

\begin{abstract}
Abstrak
Tujuan penelitian ini untuk mengetahui urgensi dan relevansi kebijakan Pemerintah dalam memperbaiki ekosistem penyelenggaraan kesehatan masyarakat dengan penguatan JKN sebagai skema asuransi kesehatan sosial yang bersifat wajib sebagai akibat adanya kesejangan antara iuran dengan manfaat yang komprehensif di masa wabah pandemi global Covid-19. Hasil penelitian menunjukkan bahwa: 1) kebijakan skema Jaminan Kesehatan Semesta (Universal Health Coverage, UHC) dalam SJSN-KIS mempunyai urgensi sebagai pemenuhan penyelenggaraan jaminan kesehatan yang terjangkau oleh seluruh lapisan masyarakat secara adil dan merata sesuai amanat konstitusi; 2) Skema sistem Jaminan Kesehatan Semesta (Universal Health Coverage, UHC) Sistem UHC telah dimodifikasi oleh Pemerintah untuk diselaraskan dengan kondisi dan tujuan penyelenggaraaan kesehatan nasional yang profesional, efisien dan efektif, dan menjangkai seluruh lapisan masyarakat;3) Skema Jaminan Kesehatan Semesta (Universal Health Coverage, UHC) yang terintegrasi antara Sistem Jaminan Sosial Nasional (SJSN) dan Sistem Kesehatan Nasional (SKN) sangat relevan bagi penyelenggaraan kesehatan masyarakat berdasarkan kerjasama, solidaritas dan empati semua warga di masa pandemi global Covid-19.
\end{abstract}

Kata kunci: Universal Health Coverage, penyelenggaraan kesehatan masyarakat

\begin{abstract}
The purpose of this study is to study the urgency and relevance of Government policies in improving the public health ecosystem by strengthening JKN as a health insurance needed to improve the compatibility between contributions and useful benefits in the future of the global pandemic outbreak Covid-19. The results of the study show that: 1) the policy on universal health insurance requirements (Universal Health Coverage, UHC) in the SJSNKIS has urgency as fulfilling the implementation of health insurance that is affordable to the whole community and in accordance with the mandate of the constitution; 2) Scheme of the Universal Health Insurance System (Universal Health Coverage, UHC) The UHC system is supported by the Government to be aligned with the requirements and objectives of national health care that are professional, efficient and effective, and reaches all communities; 3) The Universal Health Coverage Scheme (Universal Health Coverage, UHC) which is integrated between the National Social Security System (SJSN) and the National Health System (SKN) is very relevant for the implementation of public health through cooperation, solidarity, and empathy for all citizens in the global pandemic -19 .
\end{abstract}

Keywords: universal health coverage, public health administration 


\section{A. Pendahuluan}

Negara merupakan satu-satunya tumpuan dan harapan bagi masyarakat pada saat terjadi wabah pandemi Covid-19 yang telah menelan banyak korban jiwa pada saat ini. Sebagaimana tujuan dibentuknya negara, individu dan masyarakat mempunyai hak untuk memperoleh jaminan keamanan, keselamatan jiwa, dan harta miliknya dari ancaman alam maupun lawan yang berasal dari luar komunitasnya. Negara memperoleh otoritas dan legitimasi dari masyarakat untuk menjaga harmoni, melindung hak-hak privat dan komunitas serta merealisasikan kebahagiaan bersama (bonum comune).

Dalam praktek bernegara, penyelenggara negara mempunyai kewajiban untuk memenuhi seluruh kebutuhan dasar manusia sesuai dengan hakekat manusia yang utuh, yaitu keseluruhan pribadi manusia yang terdiri dari badan dan jiwa. Aristoteles menyatakan tentang kewajiban negara ini dalam tulisannya yang dekenal sebagai Etika Nicomachea, dalam bukunya "The Republic" (Sumaryono, E.; 1998).

Dalam tata kehidupan masayarakat modern, negara harus menjamin sepenuhnya hak atas kebebasan individu dan komunitas warga (civil society), keselamatan dan keamanan harta benda, serta jiwa raganya. Hak-hak ini dikenal sebagai hak dasar yang bersifat terberi (given), yang dalam konteks perkembangan negara modern kemudian disebut sebagi hak fundamental atau hak asasi. Begitu pula di saat wabah pandemi Covid19 yang melanda hampir seluruh negara di dunia sekarang ini, kesehatan merupakan kebutuhan primer bagi setiap individu dan masyarakat. Negara sebagai penanggungjawab atas keselamatan seluruh warganya, dituntut secara total untuk menjamin dan melindungi kesehatan badan dan jiwa seluruh warga dan penduduk yang berada di wilayahnya. Pemerintah sebagai pelaksana tanggungjawab, fungsi dan tugas negara dalam penyelenggaraan pelayanan publik harus bekerja keras mengatasi wabah pandemi. (Frans Magnis Suseno; 2018)

Dalam praksis kehidupan bernegara Indonesia, sarana pelayanan dan dukungan finansial bagi terpenuhinya jaminan penyelenggaraan kesehatan publik merupakan salah satu tanggungjawab negara dalam merealisasikan kesejahteraan umum. Sebagai sarana pendukung bagi pemenuhan kesehatan publik tersebut, Pemerintah telah membentuk telah membentuk Sitsem Jaminan Sosial Nasional-Kartu Indonesia Sehat (SJSN-KIS) dengan 
Administrative Law \& Governance Journal. Volume 3 Issue 2, June 2020 $\mid$ ISSN. 2621-2781 Online

Badan Penyelenggara Jaminan Sosial (BPJS), sebagai lembaga yang mengurus penyelenggaraan jaminan dan layanan kesehatan bagi masyarakat.

Badan Penyelenggara Jaminan Sosial (BPJS) dibentuk oleh Pemerintah, merupakan transformasi dari PT Askes (Persero). Hal ini berawal pada tahun 2004, yaitu saat Pemerintah mengeluarkan UU Nomor 40 Tahun 2004 tentang Sistem Jaminan Sosial Nasional (SJSN). Sebagai tindak lanjutnya, pada tahun 2011, Pemerintah menetapkan UU Nomor 24 Tahun 2011 tentang Badan Penyelenggara Jaminan Sosial (BPJS), serta menunjuk PT Askes (Persero) sebagai penyelenggara program jaminan sosial di bidang kesehatan, sehingga kemudian PT Askes (Persero) berubah statusnya menjadi BPJS Kesehatan. Melalui Program Jaminan Kesehatan Nasional-Kartu Indonesia Sehat (JKNKIS) yang diselenggarakan oleh BPJS Kesehatan inilah, Nnegara hadir untuk memastikan seluruh penduduk Indonesia terlindungi oleh jaminan kesehatan yang komprehensif, adil, dan merata.

Sejak ditetapkannya kebijakan penyelenggaraan layanan kesehatan bagi masyarakat melalui Jaminan Kesehatan Nasional dan kartu Indonesia Sehat (JKN-KIS) oleh Pemerintah, tercatat sekitar 40 juta penduduk belum terdaftar sebagai peserta program Jaminan Kesehatan Nasional-Kartu Indonesia Sehat (JKN-KIS). Itu artinya, mereka belum terlindungi kesehatannya lewat layanan JKN-KIS. Karena itu, Jaminan kesehatan semesta atau Universal Health Coverage (UHC) harus menjadi tujuan dari penyelenggaraan pelayanan kesehatan masyarakat. Pemerintah sebagai pelaksana pelayana kesehatan publik mempunyai kewajiban untuk melaksanakan tujuan UHC, yaitu: akses layanan kesehatan yang menyeluruh bagi semua warga masyarakat. Di dalam sistem Jaminan Kesehatan Semesta atau Universal Health Coverage (UHC), Pemerintah mempunyai kewajiban, tanggungjawab dan tugas pemerintah untuk merealisasikan penyelenggaraan pelayanan kesehatan bagi seluruh masyarakat secara adil dan merata. Masyarakat diseluruh pelosok daerah mempunyai hak yang sama untuk dapat mengakses jaminan layanan kesehatan oleh Negara. (Kompas; 14/11/2019)

Pada hakekatnya, prinsip dasar dan filosofi penyelenggaraan pelayanan kesehatan oleh BPJS adalah nilai-nilai gotong royong dan spirit solidaritas masyarakat yang dijiwai oleh Pancasila sebagai landasan dan pedoman hidup (fundamental norm, way of life) bangsa Indonesia. Melalui iuran dari seluruh warga masyarakat yang dikelola dan difsilitasi oleh negara melalui BPJS. Masyarakat berpartisipasi dalam membangun dan 
Administrative Law \& Governance Journal. Volume 3 Issue 2, June 2020 $\mid$ ISSN. 2621-2781 Online

merealisasikan tujuan kesejahteraan dan kebahagiaan bersama (bonum publicum/bonum comune), sebagai tujuan negara (telos) yang diamanatkan oleh konstitusi.

Mandat penyelenggaraan Jaminan Kesehatan Semesta (Universal Health Coverage) oleh negara-negara di seluruh dunia anggota PBB, termasuk Indonesia, pada dasarnya adalah merupakan kesepakatan global, Melalui PBB, dimulai dengan kesepakatan yang dibuat bersama World Health Organisation (WHO) pada tahun 1948, kesepakatan penerapan program Millenium Development Goals (MDGs) dan dilanjutkan dengan Sustainable Development Goals (SDGs).

Melalui Konstitusi, Pasal 28 UUD NKRI, Negara mengamanatkan penyelenggaraan kesehatan seluruh masyarakat Indonesia kepada Pemerintah dan seluruh badan/jabatan pelaksana pemerintahan. Secara formal, penyelenggaraan Sistem Jaminan Sosial Nasional juga telah diatur di dalam Undang-Undang No. 40 Tahun 2004 tentang Sistem Jaminan Sosial Nasional (SJSN). Berdasarkan UU No. Undang No. 40 Tahun 2004 ini, diatur tentang penyelenggaraan Sistem Jaminan Sosial Nasional yang meliputi jaminan kesehatan, jaminan kecelakaan kerja, jaminan pensiun, jaminan hari tua, dan jaminan kematian bagi seluruh penduduk melalui iuran wajib pekerja.

Berdasarkan sistem Jaminan Kesehatan Semesta atau Universal Health Coverage (UHC) ini, keberadaan BPJS mempunyai posisi sangat strategis dan penting bagi penyelenggaraan pelayanan dan sarana yang memberi ruang bagi masyarakat untuk memperoleh akses dan layanan kesehatan. Fasilitas pelayanan kesehatan yang selama ini masih menjadi barang langka dan sulit dijangkau, dengan adanya BPJS, telah menjadi sarana untuk memperoleh layanan kesehatan yang terjangkau bagi semua lapisan masyarakat. Operasional kegiatan penyelenggaraan kesehatan melalui BPJS ini didukung oleh dana yang dialokasikan dari APBN oleh Pemerintah dalam bentuk subsidi bagi masyarakat yang tidak mampu. Sumber dana lainnya, diperoleh dari iuran yang dibayarkan oleh peserta BPJS yang jumlahnya ditentukan menurut golongan dan layanan yang diberikan berdasarkan peraturan yang ditetapkan oleh Pemerintah. (Achmad Subianto; 2010)

Dalam negara demokrasi yang menjamin hak konstitusional warganya, masyarakat dapat menggunakan hak tersebut untuk menuntut pemerintah yang dipandang tidak mempunyai kinerja dan memberikan pelayanan yang baik kepada waranya. Melalui institusi peradilan, komunitas masyarakat yang tidakpuas atas pelayanan kesehatan dan 
Administrative Law \& Governance Journal. Volume 3 Issue 2, June 2020 ISSN. 2621-2781 Online

kewajiban membayar iuran BPJS menuntut hak-haknya kepada Pemerintah dengan mengajukan gugatan uji materi Peraturan Presiden (Perpres) Nomor 75 Tahun 2019 tentang Jaminan Kesehatan Nasional ${ }^{1}$. Melalui Putusan No.7 P/HUM/2020 tanggal 31 Maret 2020, Mahkamah Agung (MA) telah membatalkan kenaikan tarif tersebut setelah mengabulkan uji materi atau judicial review atas Peraturan Presiden Nomor 75 Tahun 2019 tentang Perubahan Atas Perpres Nomor 82 Tahun 2018 tentang Jaminan Kesehatan.

Dengan adanya Putusan MA tersebut, ketentuan Pasal 34 ayat (1) dan (2) Perpres Nomor 75 Tahun 2019 bertentangan dengan sejumlah ketentuan di atasnya, antara lain UUD 1945, UU Nomor 40 Tahun 2004 tentang Sistem Jaminan Sosial Nasional dan UU Nomor 36 Tahun 2009 tentang Kesehatan dinyatakan tidak mempunyai kekuatan hukum dan tidak berlaku lagi. Sebagai konsekuensi dari adanya putusan MA tersebut, pembatalan kenaikan iuran BPJS Kesehatan ini seharusnya berlaku sejak tanggal diputuskan pada 27 Februari 2020 atau tidak berlaku surut ${ }^{2}$.

Dengan menghormati putusan MA yang dalam amar putusannya telah memberi pertimbangan dari aspek yuridis, sosiologis, dan filosofis dengan tujuan untuk memperbaiki kinerja, kelembagaan, manajemen, dan sistem pelayanan Jaminan Kesehatan Sosial BPJS secara holistik, dari hulu hingga ke hilir, pertimbangan adanya defisit anggaran BPJS Kesehatan, serta perlu adanya keseimbangan dan keadilan besaran iuran antar segmen peserta, dampak terhadap kesinambungan program dan pola pendanaan JKN, konstruksi ekosistem jaminan kesehatan yang sehat, termasuk peran Pemerintah (pusat dan daerah), Pemerintah menerbitkan Peraturan Presiden No 25 Tahun 2019 tentang Perubahan atas Peraturan Presiden No. 82 Tahun 2018 tentang Jaminan Kesehatan yang didalamnya juga mengatur mengenai besaran baru iuran peserta program Jaminan Kesehatan Nasional-Kartu Indonesia Sehat (JKN-KIS). Peraturan Presiden Nomor 75 Tahun 2019 ini mulai berlaku pada tahun 2020 ini $^{3}$.

${ }^{1}$ Perkara Nomor 7 P/HUM/2020 tentang gugatan uji materi terhadap Peraturan Presiden (Perpres) Nomor 75 Tahun 2019 tentang Jaminan Kesehatan

${ }^{2}$ MA membatalkan aturan kenaikan iuran BPJS bagi peserta pekerja bukan penerima upah (PBPU) dan Bukan Pekerja (BP) yang telah berlaku sejak 1 Januari 2020 seperti tercantum dalam Pasal 34 ayat (1), (2) Perpres No. 75 Tahun 2019. Pasal itu memuat rincian kenaikan iuran BPJS Kesehatan, iuran PBPU dan BP untuk kategori Kelas III dari Rp25.500 menjadi Rp42.000. Kemudian peserta Kelas II dari Rp51.000 menjadi Rp110.000 dan peserta Kelas I dari Rp80.000 menjadi Rp160.000.

${ }^{3}$ Oleh Komunitas Pasien Cuci Darah Indonesia (KPCDI), kenaikan iuran BPJS untuk golongan I dan II yang ditetapkan oleh Pemerintah berdasarkan Peraturan Presiden ( Perpres) Nomor 64 Tahun 2020 tentang Perubahan Kedua atas Peraturan Presiden Nomor 82 Tahun 2018 tentang Jaminan Kesehatan digugat 
Melalui Peraturan Presiden No 25 Tahun 2019 tentang Perubahan atas Peraturan Presiden No. 82 Tahun 2018, Pemerintah nmelakukan perbaikan-perbaikan secara holistik sebagaimana amar putusan MA yang meliputi segmentasi peserta, penyesuaian besaran iuran, mengintegrasikan penduduk yang didaftarkan oleh Pemerintah Daerah setempat, pengaktifan peserta yang menunggak, dan memperbaiki tata kelola sistem layanan Jamina Kesehatan Nasional.

Tabel 1. Iuran Jaminan Ksehatan bgai Peserta PBPU dan BP

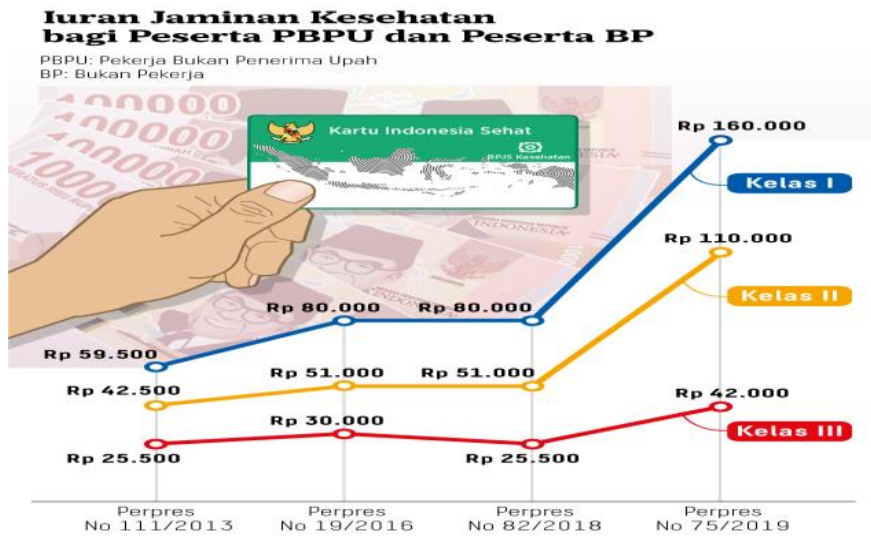

Sumber : Peraturan Presiden No. 111 Tahun 2013 juncto Peraturan Presiden No. 19 Tahun 2018 juncto Peraturan Presiden No. 75 Tahun 2019 tentang Jaminan Kesehatan; dan diolah dari berbagai sumber dan dari Litbang Kompas

Kebijakan Pemerintah untuk menaikkan iuran pogram Jaminan Kesehatan pada saat terjadi wabah pandemi Covid-19 menuai banyak kritik dan menimbulkan polemik yang berkepanjangan dari berbagai kalangan masyarakat. Dengan tidak mengabaikan adanya pandangan yang menyatakan bahwa Keputusan Pemerintah yang tidak populis, kebijakan Pemerintah menetapkan kenaikan iuran itu merupakan bagian strategi mengatasi defisit pembiayaan program tersebut yang mengalami defisit yang semakin membengkak.

Dasar pertimbangan Pemerintah melakukan perubahan dengan menerbitkan Peraturan Presiden No 25 Tahun 2019 adalah untuk memperbaiki ekosistem penyelenggaraan Jaminan Kesehatan Nasional (JKN), sebagai akibat adanya kesejangan antara iuran dengan manfaat yang komprehensif, dengan penguatan JKN sebagai skema asuransi kesehatan sosial yang bersifat wajib. Hal ini menjadi relevan dengan kondisi nasional maupun global yang sedang mengalami wabah pandemi Covid-19, yaitu 
Administrative Law \& Governance Journal. Volume 3 Issue 2, June 2020 ISSN. 2621-2781 Online

membangun kerjasama, solidaritas dan empati semua warga untuk kesehatan dan kesejahteraan bersama sebagaimana konsep dan sistem Jaminan Kesehatan Semesta (Universal Health Coverage, UHC) .

\section{B. Rumusan Masalah}

Berdasarkan pada deskripsi latar belakang penelitian, berikut ini beberapa rumusan permasalahan yang menjadi fokus kajian dan analisis: 1). Apa urgensi kebijakan Sistem Jaminan Kesehatan Semesta (Universal Health Coverage, UHC) dilihat dari perspektif penyelenggaraan kesehatan bagi masyarakat ? b). Bagaimana skema Sistem Jaminan Kesehatan Semesta (Universal Health Coverage, UHC) bagi penyelenggaraan kesehatan masyarakat? c). Bagaimana relevansi skema kebijakan Sistem Jaminan Kesehatan Semesta (Universal Health Coverage, UHC) dalam konteks penyelenggaraan kesehatan masyarakat di masa Pandemi Global Covid-19?

\section{Pembahasan}

\section{Urgensi Sistem Jaminan Kesehatan Semesta (Universal Health Coverage, UHC) bagi Akses Masyarakat untuk Memperoleh Pelayanan Kesehatan}

Jaminan Kesehatan Semesta (Universal Health Coverage (UHC) mengemuka sejak tiga belas tahun terakhir, dipicu oleh berkembangnya pemahaman akan keterkaitan antara hambatan akses penduduk terhadap pelayanan kesehatan esensial dan bermutu dengan pemiskinan keluarga akibat belanja pelayanan kesehatan. Para Menteri Kesehatan negaranegara Anggota Perserikatan Bangsa-Bangsa (PBB) bersepakat dalam pertemuan World Health Assembly (WHA) yang diprakarsai oleh PBB pada tahun 2005, untuk mengusung UHC dalam kebijakan pembangunan nasional di negara masing-masing.

Jaminan Kesehatan Semesta (Universal Health Coverage (UHC) sebenarnya bukanlah konsep baru. PBB telah memotori berbagai upaya yang mendesak negara-negara anggotanya untuk menjamin pelayanan kesehatan bagi penduduknya. Berawal dari deklarasi HAM pada tahun 1948, PBB terus memimpin gerakan-gerakan pelayanan kesehatan bagi seluruh penduduk negara-negara berkembang dan sedang membangun (New Development Country) anggota PBB. Deklarasi PBB tahun 1948 tentang "Hak Asasi Manusia" (HAM), pada Pasal 25 ayat 1 menyatakan bahwa, setiap orang berhak atas 
Administrative Law \& Governance Journal. Volume 3 Issue 2, June 2020 $\mid$ ISSN. 2621-2781 Online

tingkat hidup yang memadai untuk kesehatan dan kesejahteraan bagi dirinya dan keluarganya, termasuk hak atas pangan, pakaian, perumahan, dan perawatan kesehatan, serta pelayanan sosial yang diperlukan, dan berhak atas jaminan pada saat menganggur, menderita sakit, cacat, menjadi janda/duda, mencapai usia lanjut atau keadaan lainnya yang mengakibatkan kekurangan nafkah, yang berada di luar kekuasaannya.

Pernyataan fundamental lain yang terkait dengan hak asasi manusia, yang menjamin hak-hak dasar dibidang kesehatan adalah Konvensi ILO No. 130 Tahun 1969 (C. 130) tentang Pelayanan Kesehatan dan Santunan Sakit (Medical Care and Sickness Benefits Convension), 1969 (C. 130). Konvensi ini mengatur prinsip-prinsip perlindungan kesehatan, jaminan minimal kepesertaan, manfaat dasar, dan fasilitas kesehatan bagi para buruh disetiap negara anggota yang meratifikasi ketentuan ini.

Dukungan kepada upaya untuk menjamin hak-hak atas kesehatan juga mengemuka di dalam Deklarasi Alma Alta tahun 1978 tentang "Primary Health Care. Deklarasi Alma Ata 1978 ini merupakan kesepakatan bersama antara 140 negara, sebagai hasil Konferensi Internasional Pelayanan Kesehatan Primer (Primary Health Care), yang diselenggarakan di Kota Alma Ata, Kazakhstan. Konferensi ini diselenggarakan Septmber 1978 atas kerjasama antara World Health Organization (WHO) dengan United Nation's Children Fund (UNICEF) pada tanggal 6-12. Rumusan pokok Deklarasi Alma Ata 1978 yang disepakai oleh negara-negara yang mengikuti Konverensi tersebut adalah pernyataan bahwa Pelayanan Kesehatan Primer (Dasar) merupakan strategi utama untuk pencapaian kesehatan bagi semua (Health for All), sebagai bentuk perwujudan hak asasi manusia. (Sulistyo, Budi, Ninok Leksono (et.al), 2010)

Berdasarkan Deklarasi Alma Ata ini, negara-negara anggota PBB bersepakat bahwa untuk mewujudkan penyelenggaraan pelayana publik dibidang kesehatan dengan memberi fasilitas dan jaminan pelayanan kesehatan dasar yang meliputi (Sulistyo, Budi, Ninok Leksono (et.al), 2010):

1) Pendidikan kesehatan;

2) Peningkatan penyediaan makanan dan gizi;

3) Penyediaan air bersih dan sanitasi;

4) Pelayanan kesehatan ibu dan anak termasuk keluarga berencana;

5) Imunisasi;

6) Pencegahan dan pemberantasan penyakit endemik; 
7) Pengobatan penyakit-penyakit umum;

8) Penyediaan obat esensial.

Butir-butir jaminan pelayanan kesehatan dasar yang telah dirumuskan dalam Deklarasi Alma Ata 1978 dikuatkan lagi melalui Resolusi WHA 58.33 pada tahun 2005 tentang "Universal Health Coverage". Resolusi WHA 58.33 yang diusung dengan tema “ Sustainable Health Financing, Universal Coverage, Social Health Insurance", berisi 7 (tujuh) desakan kepada negara-negara anggota PBB untuk mereformasi sistem pendanaan kesehatan dengan mempertimbangkan jaminan semesta kesehatan (Universal Health Coverage, UHC), yaitu menjamin tersedianya pelayanan kesehatan esensial sekaligus proteksi terhadap risiko finansial akibat pemanfaatan pelayanan kesehatan ketika sakit.

Dalam suatu acara yang dihadiri oleh negara-negara aggota PBB, World Health Assembly ke-58 yang diselenggarakan oleh PBB di Geneva, pada tanggal 16-25 Mei 2005 menerbitkan resolusi WHA 58.33, yang mendesak pemerintah negara-negara anggota PBB untuk menjamin ketersediaan pelayanan kesehatan esensial bagi seluruh penduduk sekaligus melindungi penduduk terhadap risiko finansial keluarga akibat biaya pelayanan kesehatan. Rekomendasi ini memuat tentang skema pendanaan kesehatan yang bekelanjutan, jaminan kesehatan semesta serta jaminan kesehatan sosial. Ketiga gagasan dasar yang dideklarasikan pada pertemuan tersebut kemudian dipopulerkan sebagai Universal Health Coverage (UHC).

Hasil dari pertemuan negara-negara anggota PB dalam World Health Assembly (WHA) 58.33 tersebut lebih jauh mendesak para negara-negara yang menjadi anggota melakukan reformasi sistem pendanaan kesehatan dalam kerangka jaminan kesehatan semesta, dengan tujuan guna menjamin akses penduduk terhadap pelayanan kesehatan esensial dan sekaligus menyediakan perlindungan terhadap risiko finansial. Resolusi ini menghendaki dukungan lembaga legislatif dan eksekutif dan mendesak setiap negara dengan tujuan untuk:

1. Menjamin bahwa sistem pendanaan kesehatan mengikutsertakan metode pendanaan pelayanan kesehatan oleh iuran yang dibayarkan di muka. Hal ini bertujuan untuk berbagi risiko di antara penduduk, serta mencegah belanja pelayanan kesehatan yang menimbulkan bencana finansial (katastropik) dan pemiskinan individu karena pengobatan dan perawatan kesehatan. 
2. Menjamin ketercukupan dan keadilan distribusi infrastruktur dan sumber daya pelayanan kesehatan yang berkualitas, sehingga penduduk dapat memperoleh pelayanan kesehatan yang berkualitas dan berkeadilan.

3. Menjamin dana publik untuk penyelenggaraan kegiatan atau program pelayanan kesehatan akan dikelola dan diorganisasikan secara cermat dan berkontribusi pada pembangunan pendanaan kesehatan yang berkelanjutan untuk keseluruhan sistem kesehatan.

4. Merencanakan transisi menuju Jaminan kesehatan semesta sehingga mampu memenuhi kebutuhan warga akan pelayanan kesehatan dan peningkatan kualitas pelayanan, menurunkan kemiskinan, mencapai tujuan bersama internasional termasuk tujuan deklarasi pembangunan milenium, dan mencapai kesehatan bagi semua.

5. Membangun pilihan-pilihan kebijakan pendanaan pelayanan di masa peralihan sesuai dengan kondisi makroekonomi, sosiokultur, dan politik masing-masing negara menuju Jaminan kesehatan semesta.

6. Memanfaatkan peluang yang ada untuk bekerjasama antara fasilitas kesehatan pemerintah dan swasta dengan lembaga penyelenggara jaminan kesehatan di bawah pengawasan pemerintah yang kuat secara komprehensif.

Dengan mengacu pada pengalaman negara-negara anggota PBB yang telah melaksanakan UHC, berbagai metode pendanaan kesehatan, termasuk pendanaan oleh badan-badan publik dan privat, jaminan kesehatan sosial atau model campuran, dengan perhatian utama pada tata kelola yang dibangun untuk menjalankan fungsi-fungsi pokok sistem pendanaan kesehatan dievaluasi dan dirumuskan ulang untuk menjadi bahan kajian bagi keberhasilan pelaksanaan dan kerjasama pelayanan kesehatan masayarakt di negaranegara anggota PBB.

Bagi negara yang hendak mengimplementasikan sistem Jaminan kesehatan semesta, harus menyediakan berbagai faktor pendukung, yaitu:

1) Sistem kesehatan yang kuat, efisien, dan dikelola dengan baik, yaitu sebagai suatu sistem kesehatan yang mampu memenuhi kebutuhan prioritas kesehatan melalui penyelenggaraan pelayanan terpadu yang berpusat pada masyarakat dengan melalui cara dan ketersediaan unsur-unsur pendukung yang meliputi: 
a) komunikasi, informasi dan edukasi masyarakat untuk menjaga tetap sehat dan mencegah sakit;

b) pemantauan kondisi kesehatan dini;

c) kapasitas untuk pengobatan dan perawatan penyakit;

d) rehabilitasi pasen;

e) perawatan paliatif jika diperlukan.

2) Keterjangkauan - menyiapkan suatu sistem pendanaan kesehatan yang efektif, sehingga penduduk tidak mengalami kesulitan finansial saat hendak menggunakan pelayanan kesehatan.

3) Ketersediaan obat-obatan dan teknologi esensial untuk mendiagnosis dan mengobati masalah medis.

4) Kapasitas tenaga kesehatan yang kompeten dan memadai dalam menyediakan layanan untuk memenuhi kebutuhan pasien berdasarkan bukti medis yang tersedia.

5) Tindakan untuk menyelesaikan faktor-faktor sosial yang mempengaruhi kesehatan penduduk dan akses penduduk terhadap pelayanan kesehatan, antara lain pendidikan, kondisi lingkungan hidup dan pendapatan rumah tangga.

Dalam laporan tahunan World Health Report 2010 yang berjudul : "Sistem Pendanaan Kesehatan Menuju UHC", WHO menyediakan sebuah kerangka konsep dasar UHC dengan dorongan kepada masing-masing negara untuk dapat menganalisis sistem kesehatan nasional dan model pendanaan kesehatannya dalam rangka percepatan kemajuan pencapaian UHC. Kerangka konsep tersebut digambarkan dalam bentuk "Kubus 3 Dimensi UHC". Ketiga dimensi dalam Kubus UHC terdiri atas kerangka penilaian seberapa luas populasi yang tercakup, perluasan Jaminan manfaat, dan seberapa besar biaya langsung yang harus ditanggung dalam suatu sistem kesehatan nasional.

Bagai gayung bersambut, organisasi dibahwa PBB memberikan dukungan konsep UHC melalui Rekomendasi ILO No. 202 Tahun 2012 (R. 202): "Social Protection Floor". Rekomendasi ILO No. 202 Tahun 2012 ini memuat rumusan tentang batasan dasar nasional program perlindungan sosial (National Floors of Social Protection). Rekomendasi No. 202 Tahun 2012 yang populer dengan sebutan "Social Protection Floor (SPF) 2012" ini, merekomendasikan kepada negara-negara anggota ILO untuk memberi jaminan perlindungan dasar dalam sistem jaminan sosial nasional dan meningkatkan manfaatnya 
Administrative Law \& Governance Journal. Volume 3 Issue 2, June 2020 ISSN. 2621-2781 Online

secara progresif, hingga menjangkau sebanyak-banyaknya penduduk. SPF 2012 menetapkan 18 (delapan belas) prinsip penyelenggaraan perlindungan sosial.

Sebagai penegasan komitmen negara-negara anggota PBB tentang penyelenggaraan pelayanan kesehatan kepada masyarakat, WHO dalam pertemuan rutin dengan negaranegara anggota PBB, pada World Health Assembly (WHA) tahun 2000, deklarasi "Health for All by The Year 2000" ditetapkan sebagai jargon pada World Health Assembly ke-30. Melalui deklarasi "Health for All by The Year 2000" ini, sasaran utama Pemerintah negara-negara anggota PBB dan WHO dalam beberapa dekade mendatang adalah tercapainya derajat kesehatan yang memungkinkan setiap orang untuk hidup produktif ,baik secara sosial maupun ekonomi bagi seluruh warga dunia pada tahun 2000. Deklarasi "Health for All" menegaskan niat dari negara-negara peserta WHA untuk merealisasikan prinsip keadilan dalam kesehatan, partisipasi masyarakat dan aksi lintas sektoral.

Tabel 2. Target Population for UHC Goals 


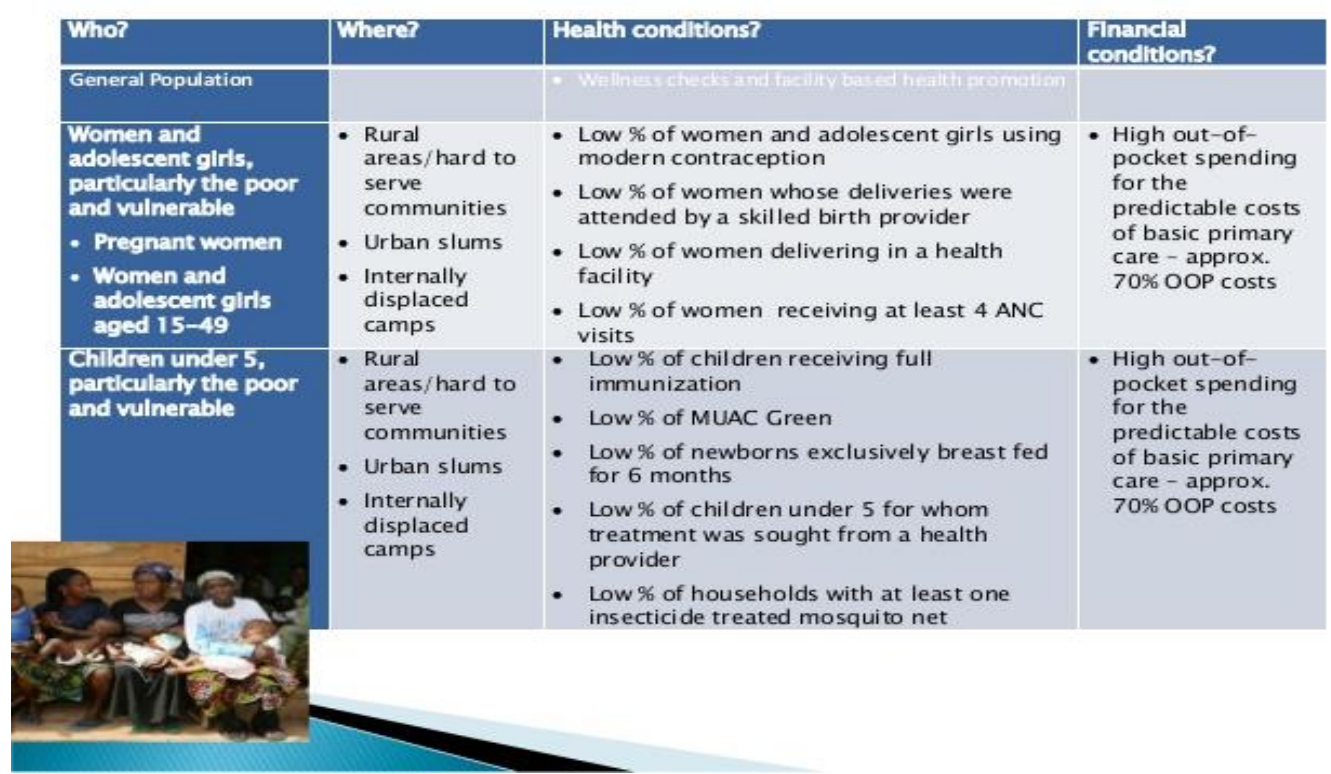

Sumber: WHO, 2018,"Universal Health Coverage: Everyone, Everywhere”

Untuk mengurangi kesenjangan kesejahteraan dan mengatasi masalah kemiskinan yang dialami oleh negara-negara anggota PBB, Majelis Umum PBB (UN General Assembly) mendeklarasikan Sustainable Development Goals (SDGs) pada tahun 2015. Di dalam Deklarasi SDGs ditegaskan lagi berupa pernyaatan tentang target penyenggaraan pelayana kesehatan publik oleh negara-negara anggota PBB, yaitu komitmen bahwa UHC akan dicapai pada tahun 2030, sebagai kelanjutan dari berbagai gerakan kesehatan untuk semua yang terdahulu bahkan sejak hak asasi manusia dideklarasikan pada tahun 1948. Deklarasi Sustainable Development Goals (SDGs) menyebutkan tentang beberapa rumusan "Target Nomor 1.3 (Kemiskinan) dan 3.8 (Kesehatan)". Rumusan target SDG nomor 3.8 adalah mencapai UHC, termasuk perlindungan risiko keuangan, akses kepada pelayanan kesehatan esensial berkualitas, dan akses ke obat-obatan esensial dan vaksin yang aman, efektif, berkualitas, dan terjangkau untuk semua penduduk".

Target SDG No.1 yang harus dipenuhi oleh negara-negara anggota PBB adalah menerapkan sistem dan ukuran perlindungan sosial yang tepat di tingkat nasional bagi semua level masyarakat. Batas waktu yang ditentukan oleh PBB adalah Tahun 2030, negara-negara anggota PBB harus berhasil memberikan perlindungan yang substansial bagi kelompok miskin dan rentan. Penentuan tenggat waktu untuk pemenuhan target tersebut bertujuan untuk mengakhiri kemiskinan dalam segala bentuknya ini sangat berkaitan erat dengan UHC. Target tersebut didasarkan pada realitas empirik yang 
menunjukkan bahwa banyak masyarakat negara-negara miskin di dunia yang berjumlah ratusan juta orang. Terjerat kemiskinan akibat pengeluaran kesehatan setiap tahunnya.

Pada peringatan Hari Kesehatan Dunia ke-70, World Health Day 2018 yang jatuh pada 7 April tahun 2018, PBB mengangkat tema "Universal Health Coverage: Everyone, Everywhere" dan tagar \#HealthForAll". Dalam perayaan tersebut, WHO menyerukan kepada para pemimpin dunia untuk memenuhi komitmen bersama UHC dalam Sustainable Development Goals (SDGs) tahun 2030. Pemimpin dunia dihimbau untuk menyusun kebijakan dan mengambil langkah-langkah konkret guna menguatkan kesehatan seluruh penduduk di masing-masing negara.

\section{Kebijakan SJSN-KIS berdasarkan Skema Jaminan Kesehatan Semesta (Universal}

\section{Health Coverage, UHC): Tulang Punggung Penyelenggaraan Kesehatan Publik}

Jaminan Kesehatan Semesta (Universal Health Coverage, UHC) adalah tujuan atau cita-cita (telos) yang harus direalisasikan oleh negara dalam penyelenggaraan pelayanan kesehatan publik dengan konsep dasar bahwa semua individu mampu mengakses pelayanan kesehatan yang mereka butuhkan dengan biaya yang terjangkau. Sistem Jaminan kesehatan semesta mempunyai makna yang sangat mendasar, yaitu tersedianya pelayanan kesehatan secara berkeadilan dan perlindungan risiko finansial. Dengan demikian, seluruh penduduk dapat mengakses pelayanan kesehatan berkualitas sesuai kebutuhan medisnya, mulai dari promosi kesehatan hingga pencegahan, perawatan, rehabilitasi, dan perawatan paliatif.

Undang-undang No. 17 Tahun 2007 tentang Rencana Pembangunan Jangka Paanjang Nasional (RPJPN), menetapkan dalam konsideran bahwa tantangan pembangunan bidang kesehatan yang dihadapi adalah mengurangi kesenjangan status kesehatan masyarakat dan akses terhadap pelayanan kesehatan antar wilayah, tingkat sosial ekonomi, dan gender; meningkatkan jumlah dan penyebaran tenaga kesehatan yang kurang memadai; meningkatkan akses masyarakat pada fasilitas kesehatan;dan mengurangi beban ganda yang penyakit, yaitu pola penyakit yang diderita oleh sebagian besar masyarakat adalah infeksi penyakit menular, namun pada waktu yang bersamaan terjadi peningkatan penyakit tidak menular serta peningkatan penyalahgunaan narkotika dan obat-obat terlarang. 
Administrative Law \& Governance Journal. Volume 3 Issue 2, June 2020 ISSN. 2621-2781 Online

Sebagai upaya untuk penyelenggaraan pelayanan kesehatan masyarakat yang dapat disakses oleh seluruh warga masyarakat secara adil dan merata, Universal Health Coverage (UHC) merupakan salah satu cita-cita Pemerintah Indonesia, yaitu usaha untuk meningkatkan jaminan pelayanan kesehatan dan derajat kesehatan akan berkontribusi pada status psikologi yang kuat. Selain itu, UHC juga menjadi jalan untuk meningkatkan akses masyarakat untuk memperoleh jaminan pelayanan kesehatan, melindungi dari resiko finansial akibat pelayanan kesehatan, khususnya penyakit katastropik. (Nila F. Moeloek; 2019)

Skema UHC di Indonesia dibangun melalui dua sistem yang menjadi konsep dasarnya, yakni: 1) Sistem Kesehatan Nasional (SKN); dan 2) Sistem Jaminan Sosial Nasional (SJSN). Sistem kesehatan di Indonesia dalam lingkup kebijakan desentralisasi diformulasikan dalam Sistem Kesehatan Nasional (SKN) berdasarkan Peraturan Presiden (Perpres) No. 72/2012 tentang SKN. SKN adalah pengelolaan kesehatan yang diselenggarakan oleh semua komponen bangsa Indonesia secara terpadu dan saling mendukung guna menjamin tercapainya derajat kesehatan masyarakat yang setinggitingginya. (Hapsara HR; 2015)

Oleh Pemerintah, kebijakan SKN ini telah dilakukan 4 (empat) kali perubahan/pemutakhiran sistem. SKN 2012 merupakan pengganti dari SKN 2009, sedangkan SKN 2009 dirancang untuk mengganti SKN 2004, selanjutnya dengan beberapa rumusan baru, SKN 2004 ditetapkan oleh Pemerintah sebagai pengganti SKN 1982. Pemutakhiran ini diperlukan agar SKN 2012 dapat mengantisipasi berbagai tantangan perubahan pembangunan kesehatan dewasa yang sesuai dengan kondisi riil masyarakat dengan jangkaun perencanaan sistem untuk jangkauan di masa depan. Oleh karena itu, SKN 2012 disusun dengan mengacu pada visi, misi, strategi, dan upaya pokok pembangunan kesehatan, sebagaimana ditetapkan dalam: a) Undang-Undang Nomor 17 Tahun 2007 tentang Rencana Pembangunan Jangka Panjang Nasional Tahun 2005-2025 (RPJP-N); dan b) Rencana Pembangunan Jangka Panjang Bidang Kesehatan Tahun 20052025 (RPJP-K). (Hapsara HR; 2015)

\section{Tabel 3.}




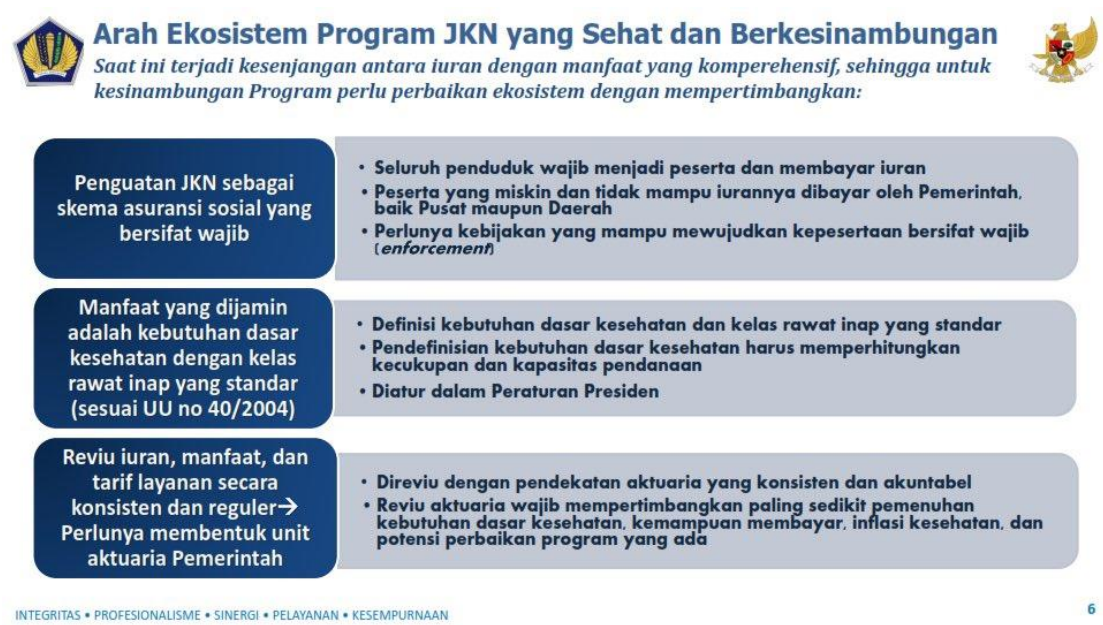

Pada tingkat daerah, implementasi SKN diterjemahkan melalui Perda, Pergub, Perbup atau Perwal, meskipun PerPres No. 72/2012 tidak secara eksplisit mewajibkan untuk menerbitkan peraturan di tingkat daerah. Fokus kebijakan Pemerintah lebih menekankan pada pengelolaan kesehatan masyaraakat berdasarkan SKN yang tanggungjawab dan pelaksanaannya harus berjenjang di pusat dan daerah, dengan memperhatikan kewenangan otonomi daerah berdasarkan kerangka Negara Kesatuan Republik Indonesia dan otonomi fungsional berdasarkan kemampuan dan ketersediaan sumber daya di bidang kesehatan.

Kebijakan SJSN adalah sebuah sistem jaminan sosial yang ditetapkan di Indonesia dalam UU No. 40/2004 tentang SJSN. Jaminan sosial ini adalah salah satu bentuk perlindungan sosial yang diselenggarakan oleh negara guna menjamin warga negaranya, untuk memenuhi kebutuhan hidup dasar yang layak, sebagaimana tertuang dalam Deklarasi PBB tentang Hak Asasi Manusia (HAM) tahun 1948 dan Konvensi ILO No. 102 tahun 1952, melalui 5 (lima) program jaminan sosial. Melalui SKN, Pemerintah menetapkan beberapa ketentuan, yaitu: 1) untuk meningkatkan akselerasi dan peningkatan mutu pelaksanaan SKN, pembangunan kesehatan perlu berlandaskan perlu berlandaskan pada pemikiran dasar pembangunan dasar kesehatan; 2) pemikiran dasar pembangunan meliputi pemikiran tentang pelaksanaan, tujuan, dan prinsip dasar pembangunan kesehatan; 3) prinsip dasar pembangunan kesehatan memerlukan aspek-aspek perikemanusiaan, pemberdayaan dan kemandirian, keadilan dan pemerataan. Dengan demikian, pemikiran dasar pembangunan kesehatan merupakan landasan penting pembangunan kesehatan untuk meningkatan akselerasi dan mutu pelaksanaan ssistem kesehatan nasional. (Nila F Moeloek; 2015) 
Program jaminan sosial dalam bidang ketenagakerjaan mencakup jaminan kematian, jaminan kecelakaan kerja, jaminan pensiun, sedangkan program jaminan sosial dalam bidang kasihan melalui jaminan kesehatan nasional. Kedua sistem tersebut, bersama dengan Nawacita kemudian menjadi landasan dalam penyusunan Rencana Pembangunan Jangka Menengah Nasional (RPJMN) 2015-2019 bidang Kesehatan yang mengacu kepada target capaian strategis upaya pokok pembangunan kesehatan yang tercantum dalam dokumen kebijakan pembangunan kesehatan.

Peraturan Presiden No. 2 Tahun 2015 tentang RPJMN 2015-2019 mengatur bahwa Kartu Indonesia Sehat (KIS) dan Jaminan Kesehatan Nasional (JKN) adalah program strategis untuk mewujudkan pencapaian UHC. JKN yang dikembangkan di Indonesia merupakan bagian dari Sistem Jaminan Sosial Nasional (SJSN) yang diselenggarakan dengan mekanisme asuransi kesehatan sosial yang bersifat wajib berdasarkan UU No. 40 Tahun 2004 tentang SJSN.

JKN bertujuan untuk memenuhi kebutuhan dasar kesehatan masyarakat yang layak, yang diberikan kepada setiap orang yang telah membayar iuran atau iurannya dibayar oleh pemerintah. Sedangkan, Kartu Indonesia Sehat merupakan program sektoral dari Indonesia Sehat yang tercakup dalam 9 Agenda Prioritas (Nawa Cita) agenda ke-5 yakni, "meningkatkan kualitas hidup manusia Indonesia". Kartu Indonesia Sehat ditujukan kepada PBI, termasuk Penyandang Masalah Kesejahteraan Sosial (PMKS) dan Bayi Baru Lahir dari peserta PBI dalam program JKN. Indonesia Sehat selanjutnya menjadi program utama Pembangunan Kesehatan Kementerian Kesehatan RI 2015-2019. 


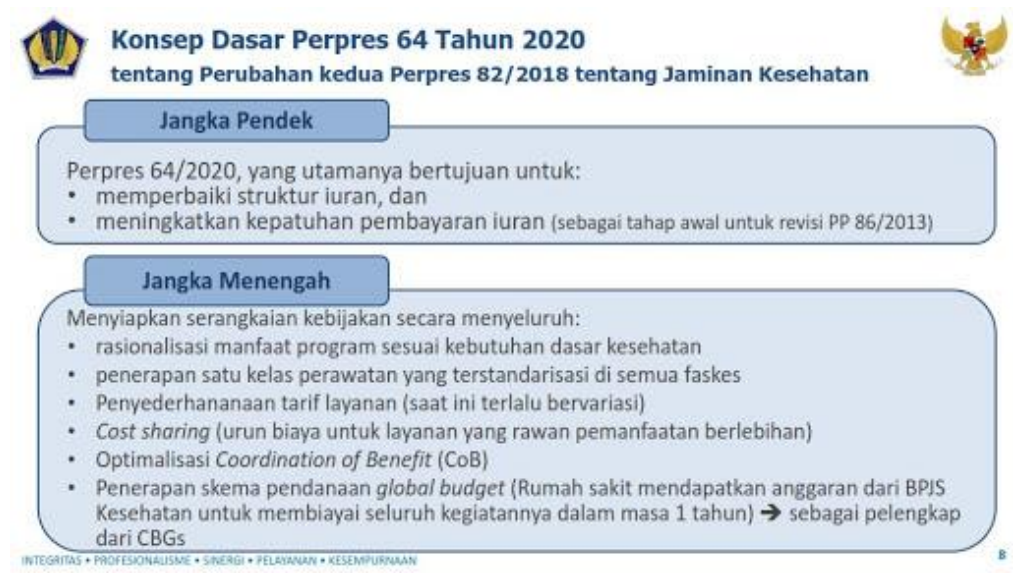

Untuk mendukung gerakan Indonesia Sehat, Rencana Strategis Kementerian Kesehatan 2015-2019 menguraikan langkah pencapaian UHC dalam RPJMN melalui peningkatan akses dan mutu pelayanan kesehatan serta penguatan upaya kesehatan masyarakat yang bersifat promotif dan preventif. Kementerian Kesehatan RI selanjutnya mengadakan tiga program dan satu gerakan untuk menunjang tercapainya Jaminan semesta JKN di tahun 2019 yang terdiri atas peningkatan upaya kesehatan masyarakat (UKM) melalui Puskesmas dan Gerakan Masyarakat Sehat (GERMAS), pembangunan fasilitas kesehatan, dan pemerataan tenaga kesehatan melalui program nusantara sehat dan wajib kerja dokter spesialis (WKDS) di daerah tertinggal, perbatasan, dan kepulauan. Keempat program tersebut merupakan bagian dari Sistem Kesehatan Nasional (SKN) sebagai amanat Peraturan Presiden No. 72 tahun 2012.

\section{Relevansi Sistem Jaminan Kesehatan Semesta (Universal Health Coverage, UHC) untuk Penyelenggaraan Kesehatan Masyarakat di Masa Pandemi Covid-19}

Indonesia adalah negara berpenghasilan menengah yang berkembang pesat dengan 262 juta penduduk dengan lebih dari 300 kelompok etnis dan 730 bahasa yang tersebar di 17.774 pulau. Kodisi demografik dan karakteristik geografik spesifik pada setiap daerah, telah menghadirkan tantangan unik untuk penerapan sistem kesehatan dan jaminan kesehatan universal, yang dikela sebagai sistem Universal Health Coverage (UHC).

Secara historis, dari tahun 1960 hingga 2001, sistem kesehatan yang dilaksanakan secara terpusat di Indonesia, pemerintah telah memperoleh keuntungan bagi terlaksananya pelayanan kesehatan terpadu kepada masyarakat, karena infrastruktur perawatan medis tumbuh pesat. Dari hampir tidak ada pusat kesehatan primer, dalam beberapa periode telah 
menjadi 20.900 pusat pelayanan kesehatan primer. Sebagai buah dari peerkembangan pusat layanan kesehatan primer tersebut, harapan hidup meningkat dari 48 menjadi 69 tahun, kematian bayi menurun dari 76 kematian per 1000 kelahiran hidup menjadi 23 per 1.000, dan tingkat kesuburan total menurun dari 5 - 61 menjadi 2 · 11. (Rina Agustina, Teguh Dartanto*, R et.al.; 2018)

Namun, keberhasilan penyelenggaraan kesehatan di seluruh wilayah negara Indonesia masih sangat tidak merata, terutama masalah kesenjangan kesehatan Ibu dan anak. Secara umum, fitur kesehatan angka kematian ibu yang stagnan sekitar 300 kematian per 100000 kelahiran hidup, dan perubahan minimal dalam kematian neonatal. Dari pespektif pendekatan satu ukuran yang terpusat untuk semua, kondisi tersebut tidak dapat mengatasi kompleksitas dan keragaman kepadatan dan penyebaran populasi di seluruh pulau, pola makan, penyakit, gaya hidup lokal, kepercayaan kesehatan, pembangunan manusia, dan partisipasi masyarakat. Tinjauan ini menggambarkan inisiatif UHC inovatif Indonesia bersama dengan peta jalan masa depan yang diperlukan untuk memenuhi tujuan pembangunan berkelanjutan pada tahun 2030. (Rina Agustina*, Teguh Dartanto*, R et.al.; 2018)

Desentralisasi pemerintahan yang diterapkan pada 354 kabupaten pada tahun 2001, dan saat ini 514 kabupaten, semakin meningkatkan heterogenitas sistem kesehatan dan memperburuk kesenjangan ekuitas. Sistem UHC baru yang diperkenalkan pada tahun 2014 berfokus pada mengakomodasi keragaman dengan fitur-fitur implementasi yang fleksibel dan adaptif dan keputusan yang didorong oleh bukti berdasarkan pada perubahan kebutuhan. Indonesia merupakan salah satu negara yang merapkan sistem UHC dengan pertumbuhan sangat pesat, mencakup 203 juta orang, dengan skema satu-pembayar terbesar di dunia, dan telah meningkatkan kesetaraan kesehatan dan akses layanan.

Dengan keberhasilan awal yang telah dicapai, tantangan penyelenggaraan kesehatan masyarakat telah muncul, seperti apa yang disebut kelompok menengah yang mengalami peningkatan status sosial, telah menyebabkan lebih sedikit jumlah orang dengan kategori sosial ini memanfaatkan dan mendaftar di UHC sebagai sarana layanan kesehatan mereka. Selain itu, biaya tinggi untuk penyakit tidak menular memerlukan fitur baru untuk pencegahan dan promosi gaya hidup sehat, dan investasi dalam sistem informasi kesehatan digital terintegrasi yang kuat untuk petugas kesehatan garis depan sangat penting untuk dampak dan keberlanjutan. 
Dalam perkembangannya, penyenggaraan pelayanan kesehatan bagi masyarakat semakin memerlukan dukungan biaya tinggi untuk penyakit tidak menular. Begitu pula dalam melaksanakan penguatan kesehatan masyarakat, Pemerintah memerlukan fitur baru untuk melakukan tindakan pencegahan dan mempromosikan gaya hidup sehat. Pada sisi lain, juga diperlukan investasi dalam sistem informasi kesehatan digital terintegrasi yang kuat untuk petugas kesehatan garis depan. Tinjauan ini menggambarkan inisiatif UHC inovatif Indonesia bersama dengan peta jalan masa depan yang diperlukan untuk memenuhi tujuan pembangunan berkelanjutan pada tahun 2030 .

Biaya tinggi untuk penyakit tidak menular memerlukan fitur baru untuk pencegahan dan promosi gaya hidup sehat. Demikian pula dengan investasi dalam sistem informasi kesehatan digital terintegrasi yang kuat untuk petugas kesehatan garis depan, sangat penting untuk mengantisipasi dampak dan keberlanjutan. Tinjauan ini menggambarkan inisiatif UHC inovatif Indonesia bersama dengan peta jalan masa depan yang diperlukan untuk memenuhi tujuan pembangunan berkelanjutan pada tahun 2030. (Rina Agustina*, Teguh Dartanto*, R et.al.; 2018)

\section{Skema Sejarah dan Arah Masa Depan Program Asuransi Kesehatan Indonesia Dari aman Hindia Belanda hingga Pelaksanaan UHC}

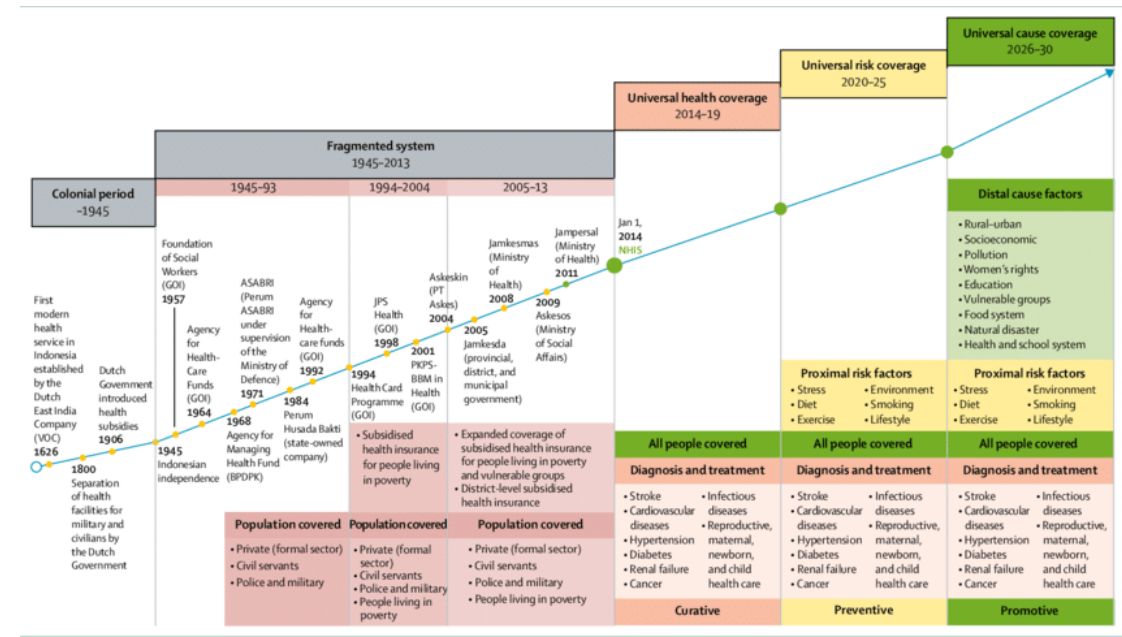

Sumber: Rina Agustina, Teguh Dartanto, R et.al.; 2018 dalam Universal Health Coverage in Indonesia: Concept, Progress, and Challenges

Dengan adanya wabah pandemi global Covid-19, penleyenggaraan layanan kesehatan masyarakat dengan menggunakan sistem UHC menjadi sangat penting untuk 
mengantisipasi dampak kesehatan bagi seluruh masyarakat dan menjadi tantangan bagi Pemerintah untuk merancang tata kelola jaminan kesehatan masal dengan rencana pendanaan yang keberlanjutan.

Menurut rumusan kebijakan WHO, Secara konseptual UHC adalah konsep yang menjamin semua orang mempunyai akses kepada layanan kesehatan promotif, preventif, kuratif, dan rehabilitatif yang dibutuhkan, dengan mutu yang memadai sehingga efektif, di samping menjamin pula bahwa layanan tersebut tidak menimbulkan kesulitan finansial penggunanya. Mitos kebijakan pelayanan kesehatan mengenai UHC di antaranya adanya pemahaman bahwa lingkup dan sasaran UHC adalah hanya sebatas pembiayaan kesehatan saja. Pandangan tersebut berbeda dengan rumusan yang sudah ditetapkan secara jelas oleh badan kesehatan dunia dibawah naungan PBB. WHO menekankan bahwa pencapaian UHC membutuhkan penguatan dari segi pelayanan kesehatan, tenaga kerja kesehatan, fasilitas kesehatan dan obat-obatan, sistem informasi, serta tata kelola pelayanan kesehatan. Selain itu mitos lainnya adalah UHC dianggap sebagai kesehatan perorangan, yang tentu keliru karena UHC mencakup pelayanan kesehatan masyarakat, antara lain promosi kesehatan masyarakat. (Lihat: Enam Mitos Universal Health Coverage (UHC))

Pemerintah Indonesia menilai kebijakan yang efektif untuk mencapai UHC adalah melalui skema jaminan kesehatan sosial untuk memperluas akses terhadap pelayanan kesehatan dan melindungi pasien serta keluarga dari kemungkinan pemiskinan akibat belanja kesehatan katastropik. Pemerintah Indonesia sadar bahwa JKN (yang cenderung pada upaya kesehatan perorangan), akan pincang jalannya apabila tidak didukung dengan pemenuhan aspek pembangunan kesehatan lainnya yakni paradigma hidup sehat melalui upaya kesehatan masyarakat di Puskesmas dan GERMAS serta penguatan pelayanan kesehatan melalui pembangunan fasilitas kesehatan dan pemerataan tenaga kesehatan.

Kebijakan Pemerintah dalam pelayanan kesehatan masyarakat dengan sistem UHC melalui sistem JKN-SKN diuji dengan adanya pandemi Covid-19. Ketangguhan tata kelola birokrasi, manajemen sumberdaya, dan profesionalitas aparatur negara dan tenaga kesehatan ditantang untuk secara optimal mengatasi wabah pandemi global Covid-19, mengingat bahwa banyak negara-negara maju secara ekonomi dan teknologi tinggi tidak menjadi jaminan untuk dapat menghindari berbagai permasalahan yang timbul dari paparan wabah ini.

Tabel 5.Perbandingan Indeks Kesehatan dan Paparan Pandemi Covid-19 
Administrative Law \& Governance Journal. Volume 3 Issue 2, June 2020| ISSN. 2621-2781 Online

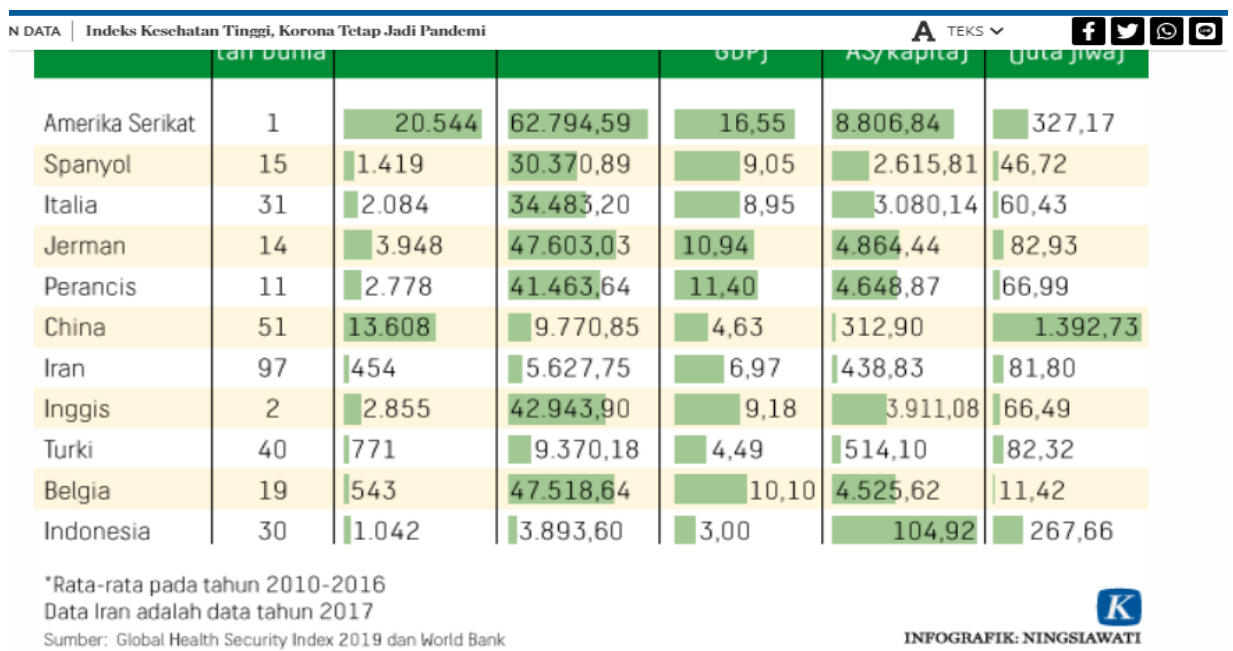

Sumber data: Harian Kompas, Tanggal 15 Maret 2020

Dampak wabah pandemi Covid-19, tidak hanya pada aspek kesehatan, tapi juga aspek ekonomi, keuangan, dan sosial (dengan bentuk interaksi barunya). Pandemi global Covid-19 menyerang semua sektor. Di bidang ekonomi, supply-demand terpukul, karena pengaruh mobilitas/pergerakan. Pertumbuhan sektor ekonomi dan tingkat kesejahteraan masyarakat di beberapa negara menjadi negatif. Tidak dapat dielakkan bahwa gelombang wabah pandemi Covid-19 mengubah arah ekonomi secara drastis hampir semua negara yang terpapar. Langkah-langkah cepat dan tepat dari pemerintah untuk memberi jaminan layanan kesehatan dalam menghadapi pandemi Covid-19 menjadi kunci utama untuk mencegah semakin banyaknya warga masyarakat yang terpapar dan menjadi korban wabah pandemi ini.

Keadaan darurat pandemi Covid-19 yang tidak pernah terduga dan diperhitungkan sebagai bencana yang dapat mempengaruhi semua sektor dan tatanan penyelenggaran negara dan pemerintahan, membuat pemerintahan-pemerintahan di seluruh dunia mengalami kesulitan untuk mengambil keputusan. Prioritas utama yang ditempuh Pemerintah untuk mengatasi wabah Covid-19 ini adalah kesehatan setiap warga dan penyelamatan masyarakat sebagai dampak pandemi dengan mengacu pada mandat jaminan kesehatan semesta (Universal Health Coverage, UHC) sebagai salah satu kesepakatan global melalui PBB dan UU No. 40 Tahun 2004 tentang Sistem Jaminan Sosial Nasional sebagai landasan formal penyelenggaraan dan pendanaan pelayanan kesehatan masyarakat. 
Administrative Law \& Governance Journal. Volume 3 Issue 2, June 2020 $\mid$ ISSN. 2621-2781 Online

Menurut studi yang dipublikasikan jurnal Critical Care Medicine pada Januari 2020 lalu, Indonesia hanya memiliki 1.910 ruang Unit Perawatan Intensif (Intensive Care Units/ ICU) dengan 7.094 unit tempat tidur (Katadata;2020). Jika dibandingkan dengan jumlah penduduk, rasio ketersediaan ranjang perawatan kritikal di Indonesia hanya 2,7 per 100 ribu populasi, sementara dari data SIRS Pelayanan Kesehatan Kementerian Kesehatan RI, terdapat 1.469 unit tempat tidur perawatan kritis yang meliputi ICU, ICCU, dan HCUatau 13,9 per 100 ribu penduduk. Kementerian Kesehatan, melalui Direktur Jenderal Pelayanan Kesehatan Kementerian Kesehatan Bambang Wibowo, saat rapat bersama Komisi IX, mengakui kapasitas layanan kesehatan yang ada, masih kurang untuk menampung pasien covid-19 yang terus bertambah. (Kompas; 2/4/2020).

Untuk mengantisipasi lonjakan pasien dan masyarakat yang terpapar Covid-19, Koordinator Relawan Gugus Tugas Covid-19, mengatakan Indonesia membutuhkan tambahan 1.500 dokter dan 2.500 perawat dalam menghadapi pandemi. Pada 2018, total ada 93.628 dokter di Indonesia. Dari jumlah itu 56.084 adalah dokter umum dan 37.544 dokter spesialis. Dengan perhitungan bahwa jumlah penduduk Indonesia sebanyak 265 juta jiwa, maka rasio ideal dokter untuk memeberi layanan kesehatan adalah sebesar 0,4 per 1.000 populasi. Hal ini menunjukkan, hanya terdapat empat dokter untuk melayani 10 ribu penduduk. Rasio ini jauh lebih rendah jika dibandingkan dengan Korea Selatan, Tiongkok, dan Malaysia yang memiliki dua dokter untuk menangani 1.000 penduduknya. Tak hanya dokter, ketersediaan perawat dan bidan juga rendah yakni hanya dua orang untuk melayani 1.000 penduduk. (Katadata; 2020)

Berangkat dari sumber data tentang ketersediaan sarana pelayanan kesehatan yang kurang memadai untuk mengatasi wabah pandemi Covid-19tersebut di atas, Pemerintah perlu mengantisipasi dengan melakukan pengadaan pembelian peralatan dan pembangunan sarana kesehatan dengan segera dan pendanaan dari APBN yang sebelumnya tidak direncanakan alokasinya. Kebijakan dan langkah Pemerintah untuk mengatasi wabah pandemi Covid-19 meliputi berbagai aspek, mulai dari segi pendanaan hingga tata kelola birokrasi serta sumber daya untuk penyelenggaraan kesehatan masyarakat.

Dibayangi oleh kombinasi antara krisis kesehatan dan ekonomi yang dihadapi dunia sebagai dampak pandemi global Covid-19, Pemerintah menerbitkan Perppu No. 1 Tahun 2020 tentang Kebijakan Keuangan Negara dan Stabilitas Sistem Keuangan untuk Penanganan Pandemi Corona Virus Disease 2019 (Covid-19) dan/atau Dalam Rangka 
Administrative Law \& Governance Journal. Volume 3 Issue 2, June 2020 ISSN. 2621-2781 Online

Menghadapi Ancaman yang Membahayakan Perekonomian Nasional dan/atau Stabilitas Sistem Keuangan, dengan pertimbangan kemendesakan dan urgensi untuk mengatasi wabah pandemi Covid-19. Melalui Perpu 1 Tahun 2020 ini, Pemerintah mengupayakan penyelamatan kesehatan dan perekonomian nasional, dengan fokus pada belanja untuk kesehatan, jaring pengaman sosial (social safety net), serta pemulihan perekonomian termasuk untuk dunia usaha dan masyarakat yang terdampak. Pemerintah mengalokasikan dana stimulus dan relaksasi fiskal yang diharapkan dapat dirasakan manfaatnya oleh tenaga medis, masyarakat, dan pelaku usaha di sektor riil serta sektor keuangan yang meliputi usaha mikro, usaha kecil, usaha menengah, usaha besar, dan koperasi secara lebih merata, yang antara lain mencakup:

a) Anggaran tambahan untuk pencegahan Covid-19 di bidang kesehatan sebesar Rp75 triliun termasuk untuk pemberian insentif bagi tenaga medis dokter, perawat, santunan kematian, pembelian alat kesehatan termasuk Alat Pelindung Diri (APD), masker, hand sanitizer, ventilator, dan persiapan rumah sakit serta berbagai fasilitas karantina;

b) Memperluas pemberian tambahan bantuan sosial sebesar Rp100 triliun bagi masyarakat terdampak Covid-19 yang sangat membutuhkan. Lebih dari 29 juta keluarga atau bahkan mencapai di atas 50\% rakyat Indonesia menikmati bantuan pemerintah baik dalam bentuk tunai, sembako, pembebasan dan diskon listrik, hingga kartu prakerja;

c) Memberikan dukungan insentif relaksasi perpajakan, bantuan lebih dari 60 juta UMKM baik dalam bentuk penundaan cicilan, subsidi bunga dan bantuan tambahan modal kerja;

d) kebijakan dalam rangka program Pemulihan Ekonomi Nasional untuk pelaku usaha di sektor riil dan sektor keuangan yang meliputi usaha mikro, usaha kecil, usaha menengah, usaha besar, dan koperasi yang kegiatan usahanya terdampak oleh COVID-19.

Penerbitan Perppu Nomor 1 Tahun 2020, yang kemudian disetujui oleh DPR menjadi UU No. 2 Tahun 2020 tentang Penetapan Peraturan Pemerintah Pengganti Undang-Undang Nomor 1 Tahun 2020 tentang Kebijakan Keuangan Negara dan Stabilitas Sistem Keuangan untuk Penanganan Pandemi Corona Virus Disease 2019 (Covid-19) dan/atau Dalam Rangka Menghadapi Ancaman yang Membahayakan Perekonomian 
Administrative Law \& Governance Journal. Volume 3 Issue 2, June 2020 $\mid$ ISSN. 2621-2781 Online

Nasional dan/atau Stabilitas Sistem Keuangan Menjadi Undang-Undang tentang Kebijakan Keuangan Negara dan Stabilitas Sistem Keuangan untuk Penanganan Covid-19 dan/atau dalam Rangka Menghadapi Ancaman yang Membahayakan Perekenomian Nasional dan/atau Stabilitas Sistem Keuangan. UU No. 2 Tahun 2020 ini merupakan sarana bagi pemerintah untuk memperoleh otoritas dalam pengelolaan dan penggunaan APBN untuk perubahan alokasi anggaran yang diproritaskan untuk bidang kesehatan, penyelamatan fiskal dan ekonomi nasional akibat pandemi Covid-19.

Dukungan sumber daya dan sumber dana untuk memfasilitasi berbagai sarana kesehatan sangat diperlukan oleh Pemerintah untuk mengantisipasi berbagai kemungkinan yang terjadi akibat pandemi. Meskipun pemerintah tidak bisa melakukan estimasi secara tepat jumlah penderita yang akan terpapar Covid-19, namun untuk mengatasi ledakan jumlah kasus warga masyarakat yang terpapar Covid-19, Pemerintah membentuk Gugus Tugas Covid-19 berdasarkan Kepres 7 Tahun 2020 tentang Gugus Tugas Percepatan Penanganan Corona Virus Disease 2019 (COVID-19).

Dalam konteks tatanan ekonomi dan kesejahteraan sosial, pandemi Covid-19, aspek kesehatan sangat terdampak, karena Covid-19 dimulai sebagai krisis kesehatan. Akses terhadap kesehatan menjadi tantangan terutama untuk lokasi-lokasi terpencil yang tak memiliki akses terhadap alat perlindungan diri (APD) dan ventilator. Untuk penyakit nonCovid-19, karena seluruh sumber daya kesehatan terfokus pada Covid-19, orang-orang yang memiliki penyakit lain, orang tua yang membutuhkan penanganan secara teratur, menjadi kesulitan mengakses fasilitas kesehatan dan obat-obatan. Layanan kesehatan terdampak lainnya, termasuk di antaranya adalah akses vaksinasi bagi anak-anak di mana separuh posyandu yang tersebar di tingkat masyarakat tutup untuk sementara, mengakibatkan penumpukan jumlah stok vaksin, seperti terungkap dari data Sistem Monitoring Imunisasi dan Logistik secara Elektronik (SMILE) yang diliris oleh United Nation Development Program (UNDP). (Kompas; 12/3/2020)

Dampak pandemi Covid-19 juga memperburuk tumbuh kembang anak. Dibutuhkan peran serta kader perlindungan anak terpadu berbasis masyarakat untuk membantu orangtua mengatasi segala risiko negatif terhadap anak yang mungkin muncul selama pandemi. Begitu pula, ada 21,84 juta kaum disabilitas di Indonesia yang akan sangat terdampak. Dalam kondisi ini dan tanpa kebijakan khusus, prinsip no one left behind, 
Administrative Law \& Governance Journal. Volume 3 Issue 2, June 2020 ISSN. 2621-2781 Online

sebagaimana dicita-citakan dalam target SDGs di Indonesia akan sulit tercapai. (Kompas; $28 / 5 / 2020)$

Secara struktur kelembagaan, keberadaan sistem UHC, yang secara formal dilembagakan melalui UU No. 40 Tahun 2004 tentang tentang Sistem Jaminan Sosial Nasional-Kartu Indonesia sehat (SJSN-KIS), memberi fondasi yang kuat untuk mengatasi permasalahan penyelenggaraan pelayanan masyarakat dibidang kesehatan. Indonesia, merupakan salah satu negara yang sudah berhasil membangun UHC yang mantap, diantara banyak negara yang berpenduduk besar. Kita dapat membandingkan dengan negara adi daya Amerika Serikat yang harus melalui proses dan perdebatan berkepanjangan. Kebijakan Obamacare hingga sekarang masih menjadi topik pertikaian politik yang hangat dan menguras energi seluruh rakyatnya. Indonesia telah mempunyai SJSN yang perlahan tetapi pasti, terus dibangun dan diperkuat secara lebih baik yang semuanya itu memerlukan dukungan danpartisipasi seluruh masyarakat.

Untuk mengurangi beban dan dampak bekelanjutan pandemi global Covid-19, Pemerintah dan masyaraakat harus bersinergi dalam membangun sistem kesehatan nasional yang kuat melalui dukungan dana berupa iuran sebagamana sudah dirumuskan dan dietatapkan. Negara-negara di dunia harus bekerja sama dan bertukar data lintas batas untuk menghentikan orang dan perusahaan menghindari pajak. Kedua, pengalihan subsidi untuk bantuan sosial pada saat krisis, terutama subsidi bahan bakar fosil. Pengalihan subsidi ini dapat menjadi jaminan sosial sekaligus mendorong pencapaian SDGs sebagaiman telah dideklarisakan sebagai bentuk kerjasama antar negara-negara anggota PBB untuk mewujudkan kesehatan universal yang berkeadilan.

\section{Simpulan}

Berdasakan hasil pembahasan rumusan masalah pada artikel ini, maka dapat dirumuskan simpulan sebagai berikut: Pertama, Urgensi kebijakan Jaminan Kesehatan Semesta (Universal Health Coverage, UHC) dilihat dari perspektif penyelenggaraan kesehatan bagi masyarakat adalah pemenuhan penyelenggaraan jaminan kesehatan yang terjangkau oleh seluruh lapisan masyarakat secara adil dan merata untuk mewujudkan kesejahteraan dan kebahagiaan yang sebesar-besarnya sesuai amanat konstitusi. Kedua, Skema sistem Jaminan Kesehatan Semesta (Universal Health Coverage, UHC) bagi 
penyelenggaraan kesehatan masyarakat adalah kebijakan penyelenggaraan kesehatan bagi masyarakat berupa JKN. Kebijakan ini mempunyai ruang lingkup yang berbeda dengan UHC. Sistem UHC telah dimodifikasi oleh Pemerintah sesuai dengan kondisi dan tujuan penyelenggaraaan kesehatan nasional, yaitu merupakan bagian dari upaya untuk pencapaian tujuan dari UHC.

Ketiga, Skema kebijakan pelayanan kesehatan untuk skema kebijakan Jaminan Kesehatan Semesta (Universal Health Coverage, UHC) yang terintegrasi antara Sistem Jaminan Sosial Nasional (SJSN) dan Sistem Kesehatan Nasional (SKN) sangat relevan dalam konteks penyelenggaraan kesehatan masyarakat berdasarkan kerjasama, solidaritas dan empati semua warga di masa pandemi global Covid-19.

Dengan rumusan simpulan dari pembahasan masalah, berikut ini beberapa saran yang dapat menjadi rekomendasi dan pertimbangan bagi penyelenggaraan UHC yang relevan dengan kondisi pandemi global Covid-10: Pertama, Penyelenggaraan SJSN-KIS sebagai realisasi konsep layanan dan pembiayaan serta jaminan kesehatan perlu dievaluasi secara berkesinambungan oleh unsur Pemerintah, Penyelenggara/pelaksana, dan masyarakat pengguna untuk perbaikan dan akuntabilitas tata kelola kelembaganaan publik; Kedua, Prinsip penyelenggaraan UCH merupakan bentuk penyelenggaraan pelayanan kesehatan publik memerlukan edukasi yang harus dilakukan oleh pemerintah dan masyarakat untuk mewujudkan kesadaran, solidaritas dan empati antar warga amsyarakat dalam tata hidup bernegara; Ketiga, Keberhasilan penyelenggaraan kesehatan yang adil dan berkemanusiaan memerlukan tanggung jawab dan etika hidup sehat dari setiap warga masyarakat

\section{E. Daftar Pustaka}

Dwiyanto, Agus, 2020, Reformasi Brokrasi Republik Indonesia, Pusat Studi Kependudukan dan Kebijakan UGM, Yogyakarta

Hadiarti , H. Hermin, 1984, Hukum dan Masalah Medik, Airlanga University Press, Surabaya

Huijbers, Theo, 2018, Filsafat Hukum, Penerbit Kanisius, Yogyakarta

Kementerian Kesehatan RI, 2009, Sistem Kesehatan Nasional, Jakarta

Moeleok, Nila F., 1999, Reformasi Kesehatan dan Visi Masa Depan, Tanpa Penerbit

Notoatmodjo, Soekidjo, 1997, Ilmu Kesehatan Masyarakat, Penerbit Rineka Cipta, Bandung 
Pan America, WHO, 1992, The Crisis of Public Health: Reflection for the Debate, Washington DC 20037, USA

Rachmat, Hapsoro, 2015, Pancasila dan Pengaruhnya pada Filsafat Pemikiran Dasar, serta Pelaksanaan Pembangunan Kesehatan, Gadjahmada University Press, Yogyakarta , Filsafat, Pemikiran Dasar Pembangunan Kesehatan, Gadjahmada University Press, Yogyakarta Press, Yogyakarta , Prinsip Dasar Pembangunan Kesehatan, Gadjahmada University

Rina Agustina, Teguh Dartanto, R et.al.; 2018, Universal Health Coverage in Indonesia: Concept, Progress, and Challenges

Sciortino, Rosalia, 2007, Mепији Kesehatan Madani, Gadjahmada University Press, Yogyakarta

Sidharta, 2016, Utilitarianisme, Penerbit Universitas Tarumanegara, Jakarta

Sulistyo, Budi, Ninok Leksono (et.al), 2010, MGDs Sebentar Lagi: Sanggupkah Kita Menghapus Kemiskinan Dunia, Penerbit Gramedia, Jakarta

Sumaryono, 1998, Etika dan Hukum : Relevansi Teori Hukum Kodrat Thomas Aquinas, Penerbit Gramedia, Jakarta

Sutarno, Hukum Kesehatan: Eutanasia, Keadilan, dan Hukum Positif di Indonesia, Penerbit Setara Press, Malang

Subianto, Achmat, 2010, Sistem Jaminan sosial Nasional Pilar Penyangga Kemandirian Perekonomian Bangsa, Penerbit Gibon Book, Jakarta

Suseno, Franz Magnis, 2019, Etika Politik, Penerbit Gramedia, Jakarta

UU Nomor 40 Tahun 2004 tentang Sistem Jaminan Sosial Nasional (SJSN)

UU Nomor 36 Tahun 2009 tentang Kesehatan

UU Nomor 24 Tahun 2011 tentang Badan Penyelenggara Jaminan Sosial (BPJS)

UU Nomor 2 Tahun 2020 tentang Penetapan Peraturan Pemerintah Pengganti UndangUndang Nomor 1 Tahun 2020 tentang Kebijakan Keuangan Negara dan Stabilitas Sistem Keuangan untuk Penanganan Pandemi Corona Virus Disease 2019 (Covid19) dan/atau Dalam Rangka Menghadapi Ancaman yang Membahayakan Perekonomian Nasional dan/atau Stabilitas Sistem Keuangan Menjadi UndangUndang tentang Kebijakan Keuangan Negara dan Stabilitas Sistem Keuangan untuk Penanganan Covid-19 dan/atau dalam Rangka Menghadapi Ancaman yang Membahayakan Perekenomian Nasional dan/atau Stabilitas Sistem Keuangan

Peraturan Presiden (Perpres) Nomor 75 Tahun 2019 tentang Jaminan Kesehatan

Peraturan Presiden No. 111 Tahun 2013 juncto Peraturan Presiden No. 19 Tahun 2018 juncto Peraturan Presiden No. 75 Tahun 2019 tentang Jaminan Kesehatan

Peraturan Presiden Nomor 75 Tahun 2019 tentang Perubahan atas Perpres Nomor 82 Tahun 2018 tentang Jaminan Kesehatan

Harian Kompas Tanggal 14 November 2019

Harian Kompas Tanggal 3 Maret 2020

Harian Kompas Tanggal 15 Maret 2020

Harian Kompas Tanggal 12 Maret 2020

Harian Kompas Tanggal 2 April 2020

Harian Kompas Tanggal 28 April 2020

Jurnal Kesehatan Vol. 6 Tahun 2012, Jakarta

https://katadata.co.id/berita/2020/05/31/penambahan-kasus-harian-corona-di-limaprovinsi-masih-tinggi 